\title{
Economics
}

2016; 5(5): 73-80

$\mathrm{http}: / /$ www.sciencepublishinggroup.com/j/eco

doi: 10.11648/j.eco.20160505.12

ISSN: 2376-659X (Print); ISSN: 2376-6603 (Online)

\section{Agriculture Economic Development Strategy in Côte d'Ivoire}

\author{
Noufou Coulibaly \\ Management and Applied Economics Department, Institut National Polytechnique Houphouët Boigny, Yamoussoukro, Côte d'Ivoire \\ Email address: \\ noufou_coulibaly@yahoo.fr

\section{To cite this article:} \\ Noufou Coulibaly. Agriculture Economic Development Strategy in Côte d'Ivoire. Economics. Vol. 5, No. 5, 2016, pp. 73-80. \\ doi: 10.11648/j.eco.20160505.12
}

Received: October 8, 2016; Accepted: October 27, 2016; Published: December 12, 2016

\begin{abstract}
Côte d'Ivoire has built its economic development on agriculture. This sector still remains the engine of its economic growth. The production system which consists essentially of extensive culture and based on natural fertility is compromised because the forest has decreased from 10.8 million hectares in 1960 to less than 1.5 million ha in 2016. This study aimed to determine an optimal allowance of the forest lands to the agricultural activities and to compare it to those cultivated, in order to appreciate the efficient use of this resource. It emerges from our study that only 2276000 hectares of land should be allocated to the agricultural sector instead of 9.5 million hectares and 12.5 million hectares of fallow land. When taking into account the prices of agricultural products from 1960 to 1981, it can be considered that the Ivorian agriculture was no efficient because the real surfaces cultivated were lower than those expected to be realized. By cons, after 1981, with the exception of 1992 and 1993, the agricultural sector was not efficient, as more forest lands were used for agriculture than was necessary. The respect of optimal allowance of forest lands for agricultural activities could have to garner an additional average annual farm income of between 3686 and 5748 billion CFA francs, as contribution of agriculture in Gross Domestic Product; illustrating the economic importance of the strategy of optimal allocation of forest lands in addition to the positive externalities that could induce. In order to reverse the trend of degradation, the agricultural development of Côte d'Ivoire should focus on: the optimal planning of land for a blooming of its different uses (agriculture, forestry, urbanization) in favor of a sustainable economic development; the development of analysis capacities, anticipation, adaptation and innovation of family farmers and all rural stakeholders; the encouragement and the raising awareness of the producers to the fixation of the cultivated areas, the intensification or modernization of the farms, the proper management of the Farmers Organizations and the proper structuring of the agricultural sectors; the control of the various balances for a sustainable development; the support of this strategy with an adequate apparatus for Farm Credit Management Council, and an adequate institutional framework.
\end{abstract}

Keywords: Optimal Land Planning, Optimal Allocation of Land, Economic Development of the Agricultural Sector, Environmental Balance, Efficiency, Sustainability

\section{Introduction}

Côte d'Ivoire, a forest country of West Africa, built its economic development on agriculture. This sector remains for a long time the engine of its economic growth. It constitutes a source of income for two thirds of the workforce, $70 \%$ of exports and 25 to $35 \%$ of Gross Domestic Product (GDP). The country is the first world cocoa producer, the 1st worldwide in rubber, the third largest coffee producer, the 5th world in oil palm and 2nd in cashew production. The production volume of food crops is estimated at 10.7 million tons of which $49 \%$ of yam, $21 \%$ cassava, $15 \%$ plantain, $6.4 \%$ rice and $5.9 \%$ corn. Food selfsufficiency is not achieved for some produce with deficits estimated at $60 \%, 88 \%, 60 \%, 80 \%$ and $60 \%$ for rice, dairy products, market garden, fisheries and meat respectively. The development model was made possible by a policy of forest intensive clearing (intensive deforestation), due at first to an encouragement of the settlers, then of the state of a migration of populations from north to south, and foreign labor (Burkinabe, Malians and Ghanaians).

With a demographic growth rate among the highest of 
West Africa (3,3\%), the population increased from 3,6 million in 1960 to 20,8 million in 2008 [1]. Such rate of population growth requires not only important socioeconomic investments, but especially a notable increase of food production.

The production system being essentially of extensive culture and based on the natural fertility was compromised, because the amount of forest land decreased from 10.8 million hectares in 1960 to less than 1.5 million ha in 2016 . And since 1980, the Ivorian agriculture is experiencing an unprecedented crisis, proving increasingly powerless to fulfill its five basic functions: feed people, increase foreign exchange resources of the State by exports, protect natural resources, guarantee to the producers a decent income and generate sustainable jobs and self-employment. Indeed, to this rise of rural densities corresponds an accentuation of the natural resource levies without real change of the operating systems and the management models. This has led to extensive deforestation, overuse of land and rangeland, generating a loss of soil fertility, a loss of biodiversity, serious erosion risks and general environmental degradation. This confined the agriculture on a very low modernization of the farms and on agriculture of picking.

Natural resource management in recent years was the focus of debate regarding the environment. It is recognized that sustainable economic growth compatible with long-term goals of environmental protection, such as conservation of natural resources for future generations, supposed an efficient management of natural resources. It is also accepted that resource management policies are intended as a means to enrich and safeguard the natural heritage, including leisure areas in protected natural regions [2]. That, insofar as a rational exploitation (forest land use) allows not only a sustainable production of the resource, but the persistence of this resource without effect of negative externality. That is why the analysis of the problem of natural resources and economic incentives is underpinned by the idea that the socially optimal use of resources is a prerequisite for the sustainability of economic development process [2]. It is the strength idea to which becomes attached our study which concerns the forest lands in Côte d'Ivoire.

Given the complexity of problems related to the regression of the vegetation cover and considering the importance of forestry and agriculture in the Ivorian economy (33\% of GDP), we believe that the resolution of these problems requires a plan of effective use of forest lands. This is why we found it appropriate to ask:

What quantities of forest lands, when taking into account its social value, should be allocated to the agricultural holding?

What basis could we hold to assure Côte-d'Ivoire meets its challenges of the current problem of the farming sector?

We think that an optimal planning of the forest lands for a best allocation of the resources to agricultural activities is a key element of the strategies to be impulse to deal with all the challenges to be raised over a very short period: increase productivity (soils, agricultural labor, agricultural capital), control the management of rural areas and ensure sustainable operating structures. The objective of our study was to contribute to the improvement of the farming sector for a sustainable economic development. Specifically, it will be a question of:

a) Determine the optimal area of forest land which should have been assigned to the agricultural activities, from 1960 to 2016.

b) Explain the gap which could exist between the situation observed in reality on the ground and the optimal areas.

c) Propose a strategy to achieve the optimal allocation (new balance) in the event that the areas observed were different from those determined.

\section{Review of Literature}

Several tools in the context of the rational management of resources were used to help the politicians to decide and guide the development policies. These tools can be presented as mentioned below. The analysis of the effects of mismanagement or the inappropriate use of the resources is made possible, according to reference [2], by the use of two related concepts that are: the Collective Opportunity Cost (CCO) of resource use which is bound with the optimal rate in which a resource should be used. It includes three elements which are: the direct costs of extraction or harvesting $(\mathrm{Ch})$, the costs that the user imposes to the future users $(\mathrm{Cu})$ and, the external costs $(\mathrm{Ce})$ bound to the resource use. What summarizes as: $\mathrm{CCO}=\mathrm{Ch}+\mathrm{Cu}+\mathrm{Ce}$. the Total Economic Value (TEV), which refers to the components of sustainable resource conservation; and includes: the consumption value $(\mathrm{Bc})$, the value for future users or option value (Bo), and the value that the resource takes in sustainable preservation condition or the existence value (Be), which is summarized as follows: $\mathrm{TEV}=\mathrm{Bc}+\mathrm{Bo}+\mathrm{Be}$.

The CCO, according to reference [2], highlights the profitcost analytical method in the management of natural resources. Indeed, the inclusion of environment-related costs in the national accounts as well as the assessment and the monitoring of natural resources are management tools of natural resources in reference [3].

According to reference [4], the forest produces a number of goods and services for which there exists a strong demand. Unlike the vast array of goods produced by the economy, private markets mechanisms have failed to solve the allocation problem with regard to multiple use services. Whatever the pattern of demand, multiple use evaluation is as much a matter of institutional form as economic method. Among the methods which may be used within a given institutional framework are: Dollar value reference points, opportunity cost, shadow prices, interagency bargaining, artificial markets and programming.

Indeed, mathematical models contributed to the management of natural resources and have been applied in several studies. These studies include that of reference [5] on econometric models, in determining the causes of deforestation. These models have two gaps in the inability to 
overcome explicitly and implicitly the definition of forest and deforestation on the one hand; and secondly, to highlight the explanatory variables and the burden of responsibility in deforestation. That is why, according to these same authors, econometrics loses its relevance in favor of general equilibrium models and optimization models.

As for the general equilibrium model described in reference [6], it also loses its acuteness because of the difficulty in modeling the behavior of actors across parameters as elasticities and the propensity to save etc. Thus, authors in reference [6], come to condemn the use of CGE models for policy evaluation.

By cons, the reference [7] reveals that the problem of effective and optimal use of resources can be solved as a profit maximization problem from different uses of this resource by the use of optimization mathematical models. Thus the author has developed a programming model to three types of land use (agriculture, urban planning, and forestry). It was followed by the study in reference [8] on forest land in Côte-d'Ivoire through optimal control model. Optimization models are presented generally as follows:

Max Z: $\Sigma$ bij.Xj, which is the objective function to be maximized;

Subject to constraints functions:

$$
\begin{gathered}
\text { इaij.Xj } \leq \text { Es } \\
X j \geq 0
\end{gathered}
$$

To solve the research problem our choice fell on the last method (mathematical optimization model), including dynamic programming method for reasons of strength, which the following section presents.

\section{Methodology}

\subsection{Method}

To meet the objectives, we found it appropriate to use the economic approach underpinned by a mathematical method of dynamic optimization including the Optimal Control. The methodology consisted of:
Modelization of the operating system of forest land as a mathematical equation while identifying all the variables necessary for the resolution;

Define scenarios from two parameters which are:

- The market value that may take ha of forest land $(5,000$ FCFA 25,000 FCFA 35,000 and FCFA 56,000 FCFA) according to our investigations with forestland owners and farmers from different areas of the country, and;

- The values that can take the social discount rate $(3 \%$, $5 \%, 7 \%$ and $10 \%$ ), according to the Central Bank and the International market.

Both parameters lead to the formulation of 16 scenarios, as shown in Table 1; which one optimal scenario $\left(\mathrm{N}^{\circ} .1\right)$, one minimal scenario $\left(\mathrm{N}^{\circ} 16\right)$ and fourteen intermediates scenarios $\left(\mathrm{N}^{\circ} 2\right.$ to 15$)$. The results of these fourteen (14) intermediates scenarios are assumed to be between the results of two previous scenarios (maximum and minimum) or confused with one of the two. Thus, only the results of maximal and minimal scenarios are required for planning and/or for agricultural policy elaboration. However, we will retain in the context of this study three (3) scenarios, which are:

- The maximal scenario, which results from the combination of the highest market value of forest land (56,000 FCFA / ha) and the highest social discount rate $(10 \%)$. This scenario illustrates a situation of strong forest land capitalization;

- The minimal scenario, resulting from the combination of the lowest market value of land and the lowest discount rate the $(3 \%)$. This scenario illustrates a situation of low capitalization of forest land; and,

- One intermediate scenario of the 14 , in order to verify the hypothesis from which the optimal result should be between the two previous and / or confounded with one of the two. Our choice has focused on the scenario $\mathrm{N}^{\circ}$ 6 , which combined the market value of forest land coming second highest $(35,000 \mathrm{~F} \mathrm{CFA} / \mathrm{ha})$, with the similar for the social discount rate $(7 \%)$. This scenario expresses an average or medium capitalization of forest land.

Table 1. Definition of scenarios.

\begin{tabular}{llllll}
\hline Number of Scenarios & Forest value(F CFA/ha) & Discount rate (\%) & Number of Scenario & Forest value (F CFA/ha) & Discount rate (\%) \\
\hline 1 & 56.000 & 10 & 9 & 56.000 & 5 \\
2 & 35.000 & 10 & 10 & 35.000 & 5 \\
3 & 25.000 & 10 & 11 & 25.000 & 5 \\
4 & 10 & 12 & 5.000 & 5 \\
5 & 5.000 & 7 & 13 & 56.000 & 3 \\
6 & 56.000 & 7 & 14 & 35.000 & 3 \\
7 & 35.000 & 7 & 15 & 25.000 & 3 \\
8 & 25.000 & 7 & 16 & 5.000 & 3 \\
\hline
\end{tabular}


Estimate agricultural and forestry average revenues per ha from 1960 to 2016, previously deflated compared to the consumer price index, based on 1985 .

\subsection{Modelization}

Solve the model with the General Algebraic Modeling System software (GAMS).

The model is written as follows:

$$
\operatorname{Max} Z=\sum_{\mathrm{T}}^{1960-2016}((1 /(1+\mathrm{R} 0) \mathrm{T}) *(\mathrm{RF}(\mathrm{T}) * \mathrm{D}(\mathrm{T})+\mathrm{RA}(\mathrm{T}) * \mathrm{SA}(\mathrm{T})-0.30 * \mathrm{RF}(\mathrm{T}) * \mathrm{SR}(\mathrm{T})+\mathrm{Fv} * \mathrm{FO}(\mathrm{T}) *(1+\mathrm{R} 0) \mathrm{T})
$$

Subject to:

$$
\begin{array}{r}
\mathrm{D}(\mathrm{T})+\mathrm{SA}(\mathrm{T})+\mathrm{SR}(\mathrm{T})+\mathrm{FO}(\mathrm{T})=\mathrm{W} *(1 /(1+0.005) \mathrm{T}) \\
\mathrm{FO}(\mathrm{T})+\mathrm{SR}(\mathrm{T})>=0.20 * \mathrm{~W}(\mathrm{~T}) \\
\mathrm{SA}(\mathrm{T})>=0.8 \mathrm{SA}(\mathrm{T}-1)+0.40 \mathrm{D}(\mathrm{T}-1) \\
\mathrm{FO}(\mathrm{T})>=0.15 \mathrm{D}(\mathrm{T}-1)+\mathrm{SR}(\mathrm{T}-1)+\mathrm{FO}(\mathrm{T}-1) \\
\mathrm{D}(\mathrm{T})>=\mathrm{D}(\mathrm{T}-1) *(1+\mathrm{R} 7(\mathrm{~T})) \mathrm{T} \\
\mathrm{D}(\mathrm{T}), \mathrm{SA}(\mathrm{T}), \mathrm{SR}(\mathrm{T}), \mathrm{FO}(\mathrm{T})>=0
\end{array}
$$

Where:

$\mathrm{SA}(\mathrm{T})$ is the area occupied by the agriculture at the moment T;

$\mathrm{D}(\mathrm{T})$ is the area in lumbering at the moment $\mathrm{T}$;

$\mathrm{SR}(\mathrm{T})$ is the surface reforested at the moment $\mathrm{T}$;

FO (T) is the forest surface at the moment T;

R7 (T) is the annual rate of deforestation growth;

$\mathrm{R} 0$ is the social discount rate, that is the interest rate of the society;

Fv is the value of the forest;

RF (T) is the income per ha of forest exploited;

RA (T) is the agricultural income per ha;

$(1 /(1+\mathrm{R} 0) \mathrm{T}$ is the discount factor, and,

" $\mathrm{T}$ " indicate that the parameters are a function of time.

The section below explains each equation to help understand the model and the system of forest land use in Cote d'Ivoire.

Equation (1) represents the total value or sum of instantaneous values from different land uses, this from 1960 to 2016 , a time horizon of 56 years. In other words, the total revenue from 1960 to $2016=$ the instantaneous income from area in lumbering discounted + the instantaneous income from agricultural activities discounted-the instantaneous cost of reforestation discounted + the instantaneous value of forest land discounted.

Equations 2 to 7 represent constraints, which reflect the system of forest land use in Côte d'Ivoire:

Equation (2) provides that the amount of land to be allocated to different activities (agriculture, lumbering, reforestation, forest stock) should always be equal to the total amount of land available in each moment. According to our investigations $0.5 \%$ of land are lost each year in the form of erosion, or whether in the form of urbanization.

Equation (3) indicates that the stock of forest every moment must be at least greater than $20 \%$ of the original amount of forest land in order to preserve the quality of the biophysical environment [9]. That is why the purpose of the Ivorian government is to have at least a cover of $20 \%$ of the territory in forest.

Equation (4) indicates that the area cultivated each year is at least equal to $80 \%$ of the cultivated area in the previous year, increased by $40 \%$ of deforested areas of the same year. According to our surveys, farmers renew $80 \%$ of their crop land and seek a new land with a natural fertility, estimated at $40 \%$; this is what reflects our equation 4 .

Equation (5) indicates that the level of forest stock is due to regeneration of $15 \%$ of harvested areas in the previous year, plus the reforested areas and the forest stock of the previous year. According to the Ivorian State Company for Forest Development (SODEFOR), about 15\% of lands in forestry for timber harvest increase the stock of forest.

Equation (6) states that logging is growing at a rate R7 (T) relative to the size of the previous year. The intensity of logging has varied depending on the period; it was very intensive in the period from 1960 to $1970,16 \%$ annual growth on average, before falling to $4 \%$ in 1971-1980 years; then it became negative in 1981 and 1990. Since 1991 growth resumed slowly and for reasons of lack of wood, we estimated that zero growth from 1996 to the end of the time horizon of the study.

The equations (7) are the conditions for non-negativity. These are terminals for the model to be solved in the positive area.

As limit to this model, it does not include the dynamics of a natural forest, due to the lack of scientific data in Côte d'Ivoire. So, according to this model, a space recently reforested is considered as forest.

\subsection{Data and Study Area}

Based on the Ivorian territory, our primary and secondary data (Table 2), were obtained respectively from surveys conducted with farmers (agricultural production yield, forestland prices), institutions such as the Ministry of Agriculture [10], Ministry of Environment [11], Ministry of Waters and Forests [12] (statistics regarding agricultural production, agricultural surfaces, forest area, forest production, agriculture and forestry incomes), USDA [13], National Institute of Statistics of Cote d'Ivoire- Ministry of Planning [1], Ministry of Economy and Finances [14] (Consumer Price Index, International agricultural products and forestry), National Bureau of Study for Development (BNETD)[15], World Bank,[16] for data on agricultural production and areas, forest stock, agricultural and forestry incomes, etc. These data allowed us to construct Table 2 below. 
Table 2. Consumer Price Index (CPI) Agricultural income deflated (AID) and Forest income deflated (FID) per ha (x 1000 FCFA).

\begin{tabular}{|c|c|c|c|c|c|c|c|}
\hline Year & CPI & AID & FID & Year & ICP & AID & FID \\
\hline 1960 & 18 & 1561 & 135 & 1988 & 115 & 82 & 13 \\
\hline 1961 & 18 & 1461 & 144 & 1989 & 116 & 171 & 158 \\
\hline 1962 & 18 & 1761 & 143 & 1990 & 127 & 88 & 91 \\
\hline 1963 & 18 & 2094 & 153 & 1991 & 128 & 207 & 565 \\
\hline 1964 & 18 & 1911 & 180 & 1992 & 130 & 203 & 181 \\
\hline 1965 & 18 & 2217 & 162 & 1993 & 133 & 38 & 411 \\
\hline 1966 & 20 & 1645 & 145 & 1994 & 266 & 497 & 740 \\
\hline 1967 & 20 & 2100 & 146 & 1995 & 266 & 466 & 694 \\
\hline 1968 & 21 & 1914 & 143 & 1996 & 266 & 434 & 1996 \\
\hline 1969 & 22 & 2005 & 149 & 1997 & 266 & 403 & 705 \\
\hline 1970 & 24 & 1883 & 138 & 1998 & 280 & 372 & 717 \\
\hline 1971 & 24 & 1888 & 132 & 1999 & 260 & 340 & 728 \\
\hline 1972 & 24 & 2013 & 151 & 2001 & 240 & 309 & 740 \\
\hline 1973 & 27 & 1704 & 190 & 2002 & 240 & 278 & 751 \\
\hline 1974 & 31 & 1758 & 1356 & 2003 & 220 & 247 & 763 \\
\hline 1975 & 35 & 2092 & 1461 & 2004 & 22 & 215 & 774 \\
\hline 1976 & 39 & 1345 & 1875 & 2005 & 220 & 184 & 786 \\
\hline 1977 & 50 & 324 & 921 & 2006 & 220 & 153 & 797 \\
\hline 1978 & 56 & 385 & 926 & 2007 & 230 & 121 & 809 \\
\hline 1979 & 66 & 277 & 1866 & 2008 & 290 & 90 & 821 \\
\hline 1980 & 76 & 102 & 1185 & 2009 & 290 & 59 & 832 \\
\hline 1981 & 82 & 43 & 782 & 2010 & 290 & 28 & 844 \\
\hline 1982 & 88 & 8 & 27 & 2011 & 215 & 210 & 856 \\
\hline 1983 & 94 & 102 & 270 & 2012 & 215 & 400 & 731 \\
\hline 1984 & 98 & 113 & 324 & 2013 & 300 & 500 & 659 \\
\hline 1985 & 100 & 184 & 404 & 2014 & 320 & 500 & 340 \\
\hline 1986 & 107 & 440 & 539 & 2015 & 320 & 500 & 245 \\
\hline 1987 & 107 & 84 & 229 & 2016 & 320 & 500 & 245 \\
\hline
\end{tabular}

Source: These data were obtained by the author calculating from data of references $[1,10,11,12,13,14,15$, and 16$]$

\section{Results and Discussion}

\subsection{Comparison Optimal and Actual Agricultural Areas}

Figure 1 below illustrates the evolution of optimal amounts of forest land that should have been allocated to the agricultural sector, compared with the amounts actually cultivated.

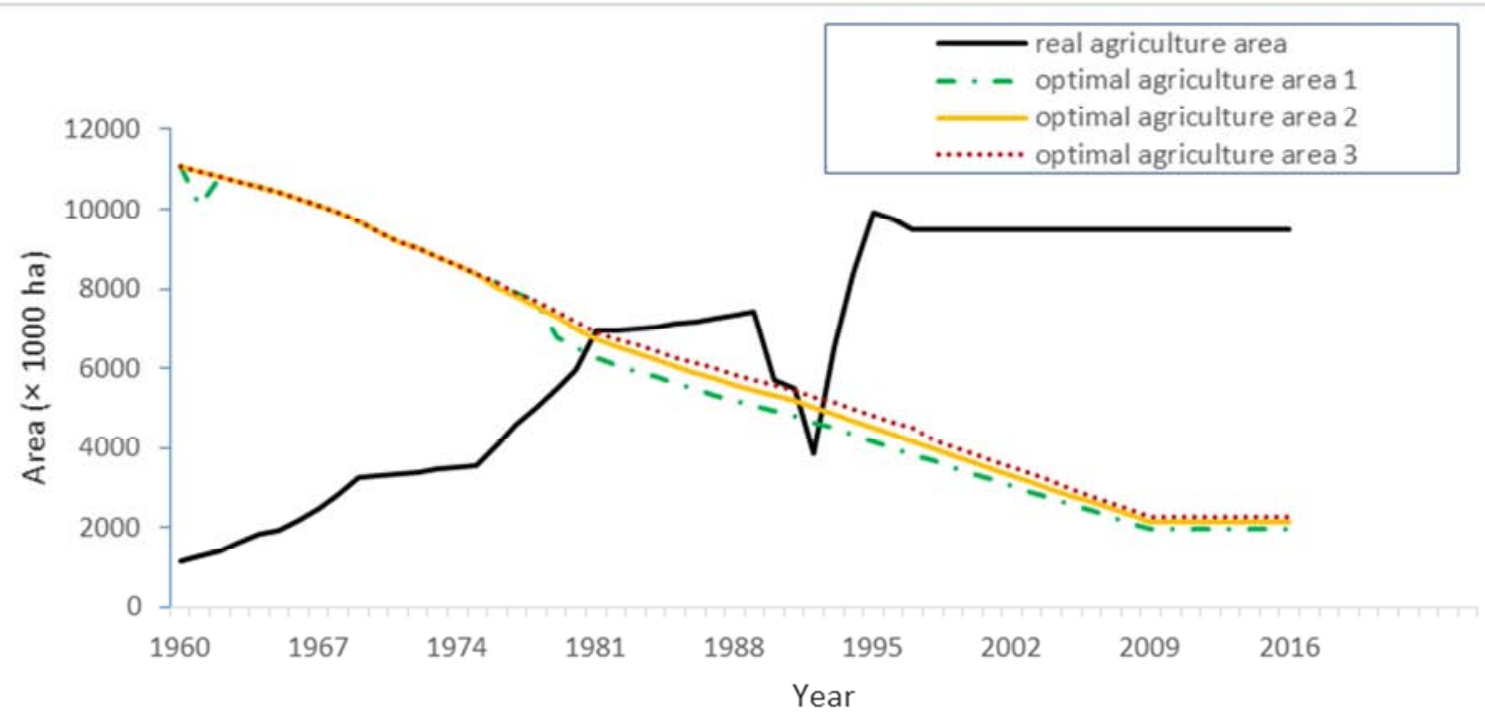

Figure 1. Evolution of optimal areas for different groups of scenarios and evolution of the real area in agriculture. 
$N B$ : In the figure above, the legend is as follows:

- The minimal scenario (No. 16) is called "optimal agriculture area 1";

- The intermediate scenario (No. 6)is called" optimal agriculture area $2 "$;

- The maximal scenario (No. 1) is called "optimal agriculture area 3" and;

- The actual agriculture area is called "real agriculture area".

It emerges from figure 1 illustrated above that, taking into account the real price of agricultural products, optimal surfaces to be allocated to agriculture depart from 11.06 million hectares in 1960 to 2.277 million hectares in 2016 .

That is to say it would have been better for the country to put more land in value in the previous years that the years after; in order to have the maximum of farm income. In fact, before 1976, the average farm income per hectare was estimated at about 2,500,000 FCFA / ha, decreasing at about 243,000 FCFA/ha from 1977 to 2016, according to our estimation in Table 2. This is to say that the economic environment was better before 1976 than nowadays.

From 1960 to 1978 , the optimal solutions (Scenario 1, 2 and 3) were almost identical, reflecting the total inelasticity of average real agricultural prices compared with optimal areas. From 1978 to 2016, there was no significant difference between the optimal solutions (Scenario 1, 2 and 3).

The intermediate scenario, called optimal agriculture area 2 in figure $\mathrm{N}^{\circ} 1$, generated a solution, which is superimposed to others, from 1960 to 1978 . However it is comprised between scenarios (optimal agriculture area 3) and minimal (optimal agriculture area 1) from 1978 to 2016 as showed in figure 1. This confirmed our hypothesis that intermediary scenarios produced solutions between scenarios maximal and minimal or confounded to one or the other.

As for the amount of forest land really in development, taking account of the work force, it starts from 1.15 million ha in 1960 to a peak of 7.406 million ha in 1989, falling to 3.837 million ha because of bad global coffee prices, and start rising to 6.5 million ha in 1993 to stabilize at 9.5 million ha from 1995 to 2016.

This stabilization of the cultivated area since 1995, can be explained by two factors:

- First, the unavailability of forest land for agriculture. This unavailability of forest land has become crucial, because of the high population growth, in link of the strong forest land demand necessary to feed populations and satisfy the State needs of revenues. The unavailability of forest land lead to social tension, thus, the government was obliged to introduce in 1998 a new land law limiting the land access only to Ivorian.

- Second, the system of data collection from the State institutions has become faulty because of the successive economic and socio-political crises that the country has gone through since 1990. Such a situation did not allow the system to collect recent small variation of used lands
Comparing the evolution of optimal allocations of forest for agricultural activities and the actual allocations as shown in Figure 1, we can see that from 1960 to 1981, the optimal surfaces which were in regression were lower than the actual agricultural surfaces. This means that less land has been used than was necessary when taking into account the value that the work could bring up. In this situation, it can be argued that the agricultural sector was not efficient, but did not harm the environment. From 1981 to 2016, except 1992 and 1993 when prices of agricultural products in the international market were very low and continually falling, real agricultural areas were higher than optimum areas across all scenarios. This reflects the fact that the agricultural sector, when taking into account market prices, used more forest land than was necessary. We can therefore state that agricultural policy was not efficient, and this waste of lands was harmful to the environment and indirectly to sustainable development.

\subsection{Causes of Agricultural Land Growth Beyond the Optimal Area}

The respect for this optimal allowance of forest lands for agricultural activities would have been able to allow garnering an additional average annual farm income of between 3686 and 5748 billion CFA francs, as contribution of agriculture in GDP, illustrating the economic importance of the strategy of optimal allocation of forest land in addition to the positive externalities that could induce. Indeed, the increase of the population pulled a more important request of agricultural products, which, according to the technology will be more or less transformed. The satisfaction of a part of this request by the imports is conditioned by the politics of public authorities regarding food self-sufficiency, the economic structures of the country and its capacity to drain outside resources. If the domestic demand of food products increases, the request of new lands will then be depend on the improvement of the productivity of the farming sector. Population growth is also reflected in an increase in domestic demand for timber and wood fuel. It leads to a further increase in labor supply. If there is not an opportunity of extra-agricultural jobs, people will be absorbed mostly by agriculture, resulting in increased of demand for land, depending also of the productivity in this sector.

The receipts of the State resulting exclusively on exports of agricultural products or agro-industrial, led this one to encourage the agricultural activities with low yields to the detriment of the forests which was considered as an inexhaustible resource. The country being integrated into the international trade and under the influence of the deterioration of the terms of trade, the State has had to encourage more production to get a higher income. In feedback to the increase in production, prices fell, and it was necessary to produce more through extensive agricultural activity, to the detriment of forest lands. The poverty led the rural population to use more and more resources to increase its income. But, as crop production increased at the expense 
of forest land, prices fell by the law of supply and demand. And more poverty sets in, more new technology becomes increasingly inaccessible, intensifying increasingly impossible and the development increasingly compromised. These statements confirmed once again those of reference [17], concerning the consequences of macro-economic policies. Indeed, the traditional production system is the most dominant [18]. Combined with the effects of macroeconomic policies and the evolution of the population, it causes spectacular growth of cropped area and fallow land at the expense of forest lands as shown in Figure 1. If we added to cultivated area those destroyed by shifting cultivation, agricultural land would be 2.5 times higher than that determined in our study. However, apart from yet very important fallows, crop areas were higher than those considered optimal since 1981, illustrating the waste and inefficient use of forest lands in this activity.

\subsection{Strategies to Enable the Actual Agricultural Area Reach Their Optimum Level}

In light of the above, it is not incongruous to suggest that the Ivorian agricultural sector is nowadays an unprecedented crisis, are proving increasingly unable to meet its five basic functions: feeding people, increase the state's foreign exchange resources by exports, protect natural resources, guarantee producers a decent income and generate sustainable jobs and self-employment.

To quickly respond to the scale of different problems raised, four actions must imperatively be conducted:

- First, for us, it is vital that Producers can acquire and use scientific and technical knowledge that enable them, especially for new generations, to keep pace with current developments. We think that the professional and technical training in the agricultural and rural sector more refocused on producers, and the Board of Management of farms and agricultural cooperatives (farmers' association) as supported in reference [19] are the elements- key strategies to stimulate, and to deal with the accumulation of challenges faced in a very short period in order to:

- Increase the productivity of soils, agricultural labor, agricultural capital,

- Master the management of rural areas (planning of the forest lands for its various uses, at the village, the Sub-prefecture, the Department, the Region levels and, finally at the National level),

- Ensure the sustainability of the operating structures,

- Lead to the control of the balances for a sustainable development.

- The Second immediate action that might be conducted to reduce wastage of forest land capital is the fixing, the modernization of farms and compliance with optimal amounts of forest land allocated to agriculture as determined by our model.

- The third action to be undertaken would be to develop clear and reassuring texts, that can lead to sustainable property management, strengthen the monitoring capacity, governance and especially support of the state; because according to reference [20] development of the agricultural sector can be achieved in parallel with the development of downstream and upstream activities (supplies, storage, processing, distribution ...), like all services (track and road, health, education, commerce, transport, crafts ...) involved in maintaining the population in rural areas. Establish an effective system for farm management advice and professional agricultural organizations.

- And finally, as the fourth action given the critical stock of the forest, it would not be incongruous to suspend logging in favor of the proposed civil lucrative reforestation and to glimpse timber imports from neighboring countries such as Guinea, to meet the needs of factories and population; and thus guaranteeing employment in the sector of the wood industry (forestry).

\section{Conclusion}

The objective of this study was to determine the optimal allocation of forest land to agricultural activities and compare them with those cultivated to appreciate the efficient use of this resource. It appears from our study that only 2.276 million ha should be allocated to the agricultural sector instead of 9.5 million hectares and 12.5 million hectares of fallow. And when taking into account the prices of agricultural products from 1960 to 1981, the Ivorian agriculture was not effective because the real agricultural areas were lower than those expected to be realized. By cons, after 1981, with the exception of 1992 and 1993, the agricultural sector was not efficient because more of forest land was used for agriculture than was necessary. The respect for this optimal allowance of the forest lands for the agricultural activities would have been able to allow garnering an additional average annual farm income of between 3.686 and 5.748 billion F CFA, as share of agriculture in the Gross Domestic Product, illustrating the economic importance of the strategy of optimal allocation of forest land in addition to the positive externalities that could induce. For a long time remained appropriate to their context, traditional systems of agricultural production in Côte d'Ivoire now show signs of obsolescence which explain that the agriculture fills more and more with difficulty its functions in the economic and social development. To reverse the trend of degradation, agricultural development of Côte d'Ivoire should focus on:

Optimal planning of land for a development of its different uses (agriculture, forestry, and urbanization) in favor of sustainable economic development;

The development of analytical skills, anticipation, adaptation and innovation of family farmers and all rural stakeholders. The development of these capabilities through access to information, the acquisition and mastery of new knowledge adjusted to local practices and knowledge 
through the implementation of new participatory research approaches. In other words, vocational and technical training in the agricultural and rural sector refocused on more producers remains a good alternative to stimulate, and to deal with the accumulation of challenges faced in a very short period in order to increase productivity (soil, agricultural labor, agricultural capital), to control the management of rural areas (planning by this village, SubPrefecture, Department, Region, and finally National), to ensure the viability of operating structures and lead to the mastery of different balances for sustainable development.

Encouraging and educating producers in the fixing of cultivated land, the intensification and modernization of farms, the orderly takeover and proper structuring agricultural sectors;

Accompanying this strategy with adequate apparatus for Farm Credit Management Council, and an adequate institutional framework.

\section{References}

[1] Ministère du Plan. Stratégie de relance du développement et de la réduction de la pauvreté, 2009, Institut National des Statistiques, "La Côte d'Ivoire en Chiffre" 1980-1990, Compte des Nations -1960-89 et Tableau Ressources Emploi (TRE) 1990-2013, Statistiques économique 2015.

[2] D. W Pearce. "La gestion des ressources naturelles renouvelables et les incitations économiques"Organisation de coopération et de développement économiques, 1987 pp. 1288 .

[3] W. Leontief, "Les repercussions de l'environnement sur la structure Economique: Une approche Input-Output", the review of Economics and Statistics, Vol III, N³, Août 1970.

[4] G. R. Walter; Economics of Multiple-Use Forestry. Journal of Environmental Management, 5 (1977), pp. 345-356.

[5] Lugo A., Schmidt R. et Brown S., "Tropicalforsts in the Carribbean", Ambio, pp. 318-324, 1981.

[6] I. Cléroux et J. M. Salles“ Modélisation économique de la dynamique des forêt: Une revue de littérature", Cahiers d'économie et sociologie rurales numéro 41,pp. 92-147, 1996.

[7] McConnell, K. E., The Quantity of Land in Agriculture. Northeastern Journal of Agriculture and Resource Economics, (18), 2, 1989.

[8] S. Ehui and T. Hertel, "Deforestation and Agricultural Productivité in the Côte d'Ivoire" American Journal Economics Association, August 1989, pp. 702-711.

[9] A. Aké et B. Dian, "Développement Agricole et Protection de la Forêt: Quel Avenir pour la Forêt Ivoirienne?" Compte rendu de la XII e réunion de l'Association pour l'Étude Taxonomique de la Flore d'Afrique Tropicale (AETFAT), hamburg 1990, pp. 169-175.

[10] Ministère de l'Agriculture. Annuaire des Statistiques Agricoles et Forestières", 1900-1989, 1992, 1994, "Plan Directeur du développement agricole 1992-2015" Fevrier 1997, 165 p. «Rapport d'activité" et statistique agricole 19802016.

[11] Ministère de l'Environnement. "Environnement et Développement" Rapport National sur l'état de l'environnement en Côte d'Ivoire, 5 juin 1991 à Abidjan, 116 p. "Livre blanc de l'environnement de Côte d'Ivoire" Plan National d'Action pour l'Environnement (PNAE-CI), Novembre 1994, 179 pp.

[12] Ministère des Eaux et Forêts. "Le Ministère des Eaux et Forêts Genèse, Activités et Perspectives", Rapport Direction du Domaine Forestier et du Reboisement, Décembre 1986, 121 p. " Plan Directeur forestier 1988-2015" Décembre 1988, 87 p. et rapports d'activité 1982-2014; Rapports d'activité SODEFOR 1990-2015.

[13] USDA, "Sustainable Resource Use and Global Food Security, Sub-Saharan Africa" Agriculture resource and environments Indicators, Economic Research Service, Chapter 7.1, 18P, 2000. "Resources Policies and Agriculture Productivity in Sub-Saharan Africa" Economic Research Report №14, Fev 2013. Base on "World agriculture: Trends and indicators, SubSaharan Africa-" Data.worldbank.org.

[14] Ministère de l'Economie et des Finances "Banque des données financière" 1996-2000.

[15] BNETD, Département agriculture «Statitiques agricoles, forestières et d'élevage», 1990-2014.

[16] Banque mondiale "Revue du secteur agricole, Côte d'Ivoire" Document de travail, Oct. 1994, 107 p."Vers un développement durable sur le plan environnemental en Afrique de l'ouest", Document de travail, janvier 1996, 44 p. "Plan National de Développement de Côte d'Ivoire" 2012."World agriculture: Trends and indicators, Sub-Saharan Africa-" Data.worldbank.org.

[17] T. Koné "Impact du cadre économique sur la gestion de l'environnement" Communication au séminaire national de lancement du PNAE-CI, Ministère de l'Environnement, 19-21 mai, 1992.

[18] Noufou Coulibaly, «Déforestation et Activités Agricoles en Côte d'Ivoire: Recherche d'un nouvel équilibre», 1998, Thèse de Doctorat (Ph.D) à l'Université Laval, Québec, Canada, $144 \mathrm{P}$.

[19] A. Maragnani, «Enjeux de la formation Professionnelle et Technique dans le secteur agricole: Cas de l'Afrique de l'Ouest», 2008, 24P.

[20] J. P. Tonneau, D. Louppe, F. Lançon, E. Vall, O. Mikolasek, F. Ruf, «Etude prospective sur le développement de l'agriculture en Côte d'Ivoire », CIRA- France, 117p, mars 2015. 